\title{
A RHAPSODY IN B
}

\section{ELSE MARIE BUKDAHL: THE RECURRENT ACTUALITY OF THE BAROQUE}

\section{COPENHAGEN: CONTROLUCE, 2017. 260 PAGES.}

ISBN: 9788792172044

The author is the former and legendary president of The Royal Academy of Fine Arts in Copenhagen, where she reigned during a significant period (1985-2005). As an art historian, she studied aesthetic critique (specialized in Diderot), contemporary art, and the Baroque. The volume here reviewed summarizes a considerable amount of her former work on the subject, the artists involved, and the theories that underpin subject and hypothesis: a transhistorical Baroque.

As to the subject of the book, the main interest is thus the historical Baroque art and its 'recurrence' in contemporary art. Does the Baroque in some sense actually 'recur'? Periods in art history do not normally do so, but a special case is made here for this phenomenon. The historical Baroque in fact attracted modern transgressive philosophers, and their attention to the artistic excesses of the Baroque in turn attracted modern artists, whose baroquisms again attracted the philosophers, and mutual attraction continued, that is, continues into today's art and art thinking.

Bukdahl's book, which is richly, even lavishly illustrated, starts with an overview mentioning the obligatory theorists, Heinrich Wölfflin, Henri Focillon, Eugenio d'Ors, but then also, through Walter Benjamin, the newer generations, Mario Perniola, Guy Scarpetta, Omar Calabrese, and Umberto Eco, shortly; then Severo Sarduy with Roland Barthes and Jacques Lacan, and Jean-François Lyotard, Jean Baudrillard, Michel Foucault; and in particular Christine Buci-Glucksmann and Gilles Deleuze, the latter couple destined to somehow sign the overarching perspective of the book's analyses.

In the second chapter, we find a gallery of themes presented as a characteristic of Baroque art. These include: infinite space as in Giordano Bruno's and Blaise Pascal's thinking; visual symbols such as the mirror (examples by Velázquez, Caravaggio); labyrinths, libraries, metamorphoses, ruins, masks and theatre, light, water, fire... 
"Although there are many different opinions about the definition of these essential qualities, art historians, philosophers, aestheticians and artists agree that the Baroque worldview is dominated by a preference for the following basic concepts: infinity, instability, reflexivity, fluidity, vanity, transformation, the transience of human life, the fragmentary, the chaotic, multiplicity, and the uncertain and floating relationship between dream and reality. A number of other distinguishing features associated with the Baroque worldview are: a preoccupation with the dynamic aspects of space and nature, the oscillation between the macroscopic and the microscopic, the active role of the viewer, intervisuality, the unreliability of reality, and a strong sense of openness. All these essential conditions and basic concepts of the Baroque worldview are frequently expressed or suggested by central symbols, formal patterns, and other visual devices in both art and architecture.” (p. 33)

Thus, behind this cascade of concepts, there is a particular Baroque worldview. The third chapter tries to get a grip on this by shortly presenting a selection of modern philosophers' interpretations of it, again: Benjamin, Foucault, Perniola, Buci-Glucksmann, and Deleuze. I summarize:

Benjamin had studied with Wölfflin in Munich; he felt that Paul Klee's Angelus Novus (1920), like the angel in Albrecht Dürer's Melancholia (1514), was an allegory, in the sense of The Origin of the German Tragic Drama (1928), of world history as a chaotic and destructive display of passions, but also of a hope for redemption.

Foucault expressed his view of the Baroque in his analysis of Diego Velázquez' Las Meninas (1656). This painting visualizes the Baroque as a transition from the Classical age to modernity. It does so by placing the ordinary human viewer in the position of the royal couple in front of the scenario. Lacan has protested and pointed out that the painting stares back at the viewer, which makes it even more modern. He also referred to René Magritte, about whose work Foucault wrote an essay. The critique of representation is different in the two structuralists: One stresses the multiplicity of viewpoints in the scenario, the other the viewer's being seen. In the last part of the book, Picasso's cheerful re-creations of the painting are of course mentioned.

I would like to venture a supplementary observation in the line of Lacan's remark. In Las Meninas, the viewer - king, queen or else - is imaged four times, 1) by the mirror, 2) in the eyes of the maids of honour, 3) in the eyes and hands of the painter, 4) by the chamberlain 
in the doorway, the other Velázquez, who has access to the painter's work and can compare it critically to the motif, the viewer. This means that viewer representation in this sense (of being-seen) is (1) causal, then (2) intentional, then (3) intentional-expressive, and finally (4) meta-intentional, critical. The progress from (1) to (4) takes us as viewers from pure perception to being-seen, from there to emphatically being conceptualized in art, and eventually to being critically viewed as performing on stage before the artist and the competent spectator. This 'reading' would correspond closely to the critical theatricality in Velázquez' contemporary Pedro Calderón's play La Vida es Sueño (1636).

Perniola discussed Bellarmino's and Loyola's solution to the theological problem of how to handle religious images; between iconophilia and iconoclasm there exists a third path to follow: The artistic image can be seen as a simulacrum, an autonomous construction in its own right, comparable to Benjamin's allegory, created to activate the senses and to thereby stimulate the spiritual imagination of the believer, who is made to feel the presence of the religious content. In Perniola's view, the concept of simulacrum applies equally well to modern and contemporary imagery in digital media; images are detached from reference and are no longer copies of an original but instead circulate as self-referential iconic entities; this idea inspired in the 1980s a generation of neo-figurative artists designated as Transavantguardia, Heftige Malerei, New Image Painting, The Young Wild Ones (Danish: De Unge Vilde). By the way, Bukdahl could have mentioned the important role of Jean Baudrillard in the development of the theory of simulacra. Lyotard is mentioned but gets rather short shrift; his reactivation of Kant's aesthetics of the sublime would also deserve a tribute.

Buci-Glucksmann opposes classicism and the Baroque as a parallel to the opposition of modernism and the Postmodern. On one side, rationality, science and Descartes, which she associates with perspectivism, positivism, and bureaucracy. On the other side, the madness of vision and the body, its infinite jouissance, desire, instability, dynamism - themes she seeks to find in MerleauPonty's phenomenology of painting and especially in Lacan's psychoanalysis, and his comment to Holbein's The Ambassadors (1533) with its famous anamorphosis of a skull. Spatial variations from emptiness to fullness, from nothing to everything, contrasts that may signify creation ex nihilo and lead to miracles or catastrophes, lead her to foregrounding another concept: that of the palimpsest. The overlayering of traces and meanings, or 
quotations of images in images, constitute an 'archaeology' that she wants to find again in contemporary art (Arnulf Rainer, Anselm Kiefer, and finally ORLAN).

Deleuze worked on the Baroque in his book on Leibniz, Le pli (The Fold), 1988. He used the German philosopher's Monadology to show that Descartes' dualism could be overcome, and indeed was by definition overcome, in the monist doctrine of the omnipresent monads equipped with both body and soul. The infinite number of indistinguishable monads agglomerated into finite things by 'folding' and thereby creating apparent discontinuities in continuity, following the orders of the creative God who established the harmonic universe where everything is connected to everything. All forms are folds in this sense, and especially important of course are the folds in tissue such as those in Bernini's Ecstacy of Saint Teresa or El Greco's Count of Orgaz. In this monistic and 'manifold' perspective of the universal folding and unfolding of folds, all theories of representation, simulacra, theatricality, illusion, etc. finally collapse into spiritual presence.

"But the essence of the Baroque entails neither falling into nor emerging from illusion but rather realizing something in illusion itself, or tying it to a spiritual presence that endows its spaces and fragments with a collective unity. [...] The Baroque artists know well that hallucination does not feign presence, but that presence is hallucinatory" (p. 145).

Here is the smartest formulation in Deleuze's entire work: The monadic subject becomes the nomadic subject, since in modern art everything is an ungrounded process. This happens in Dada, in Burroughs, in Borges, in Pollock, Rauschenberg, Hantaï, Morris, the steel sheets of Serra, in the roofs of Gehry, the wrappings of Christo...

Bukdahl mentions Michel Serres, whose monumental study of Leibniz prepared Deleuze's work. Curiously though, she forgets Serres' Les cinq sens (The Five Senses), 1985, his masterful contribution to this discussion. And nobody in this 'folding'-based discourse seem to remember that Leibniz' mathematical results, the differential calculus, based on Descartes' ground-breaking mathematical work, was the prerequisite for the mathematicianphilosopher René Thom's catastrophe theory, without which the concept of fold - alias le pli, the simplest of the elementary catastrophes - could not have become an ontological notion as it is in Deleuze. Thom explains that since the R2 topology of the potential $y=x 3+a x$ acquires a minimum when $a$ is negative, 
whereas the minimum disappears by $a=O$, the $a$ variable can be interpreted as a control parameter regulating transitions between being (=minimum) and nothingness (= no minimum), because a convention has referential systems taking minima as attractors, yielding system states. The ontological overgeneralization of the notion of fold in Deleuze unfortunately leads to an empty theory of everything, accounting for minds, bodies, forms and un-forms, souls and angels, gods, art, presence and spirituality, but without contributing any intelligible knowledge to these things or ideas. Reducing everything to one concept is just as inoperative as Leibniz' Monadology - by which he wanted to offer a compromise between Descartes' and Spinoza's ontologies - would be in today's particle physics.

The last chapter presents a rhapsody of observations on the Baroque in different contexts. The mathematics of fractals have fascinated modern artists; the fractal density of layered forms has indeed attracted some researchers' attention to the density of Baroque spaces. A range of Baroque-like works using the inventory of canonical gestures is listed and described here: Mona Hatoum, Jeff Koons, Joana Vasconcelos, Olafur Eliasson, Ernesto Neto, Robert Morris, James Metcalf - and then, not surprisingly, the 'great Danes' Hein Heinsen, Mogens Møller (where is Stig Brøgger?), and their strong students Øivind Nygård, Elisabeth Toubro, Morten Stræde, Søren Jensen, and Henrik B. Andersen (the latter is a fervent admirer of Deleuze's thinking and explicitly links his sculptural work to it). Bukdahl shows a pictorial work by Adam Saks - but where are Christian Lemmerz and Michael Kvium? To me, these two would seem the prototypical incarnations of contemporary Danish Baroque art. Likewise, Torben Christensen's use of orgasm photos was a direct reference to Saint Teresa and would directly fit the jouissance theme in Buci-Glucksmann.

Cézanne studied and copied Rubens, and Picasso 'copied' Velázquez and El Greco; Francis Bacon dramatically rephrased Velázquez' pope Innocent. Bukdahl finally mentions and shows works by Louise Bourgeois and the Japanese Mariko Mori. The Baroque is to be found everywhere.

In the conclusion, Bukdahl writes:

"In theirview [referring to Benjamin, Foucault, Buci-Glucksmann, and Deleuze], the Baroque is, first and foremost, a way of thinking, revealing new dimensions in our dark age and awakening an understanding of art and space. By doing so, their work places our Western cultural memory on a more solid and 
open basis and allows dimensions of a forgotten inspiration to return. That is why their philosophical procedures provide us with the capacity to learn and adapt from previous experiences, while building new relationships in the spiritual world and our daily lives. There is, therefore, also an existential aim, which attains a visual form. The encounters between the art of the Baroque and the work of contemporary artists - a work that contains a knowledge of life and matter in its own right can perhaps break down traditional boundaries in our lives and provide us with greater insight. It is precisely because art can visualise experience and create new visions of life that it is an important tool for enabling us to orient ourselves in a destabilised world, a condition our era shares with the Baroque period" (pp. 238-239).

We should always learn from the past. However, why is the Baroque a particularly relevant source of learning? Recapitulating, Bukdahl thinks that Buci-Glucksmann "found roots in Baroque art for a new definition of 'modernity' and 'reason', which is liberated from modernism's progressive view of history, closed concept of unity, totality and universality" (p. 241). That is a rather polemical statement, though very common. It stems, I must add, from Lyotard's 1979 essay on the postmodern condition, where he ascribes an eschatological view of history to modernity, in order to oppose it to a preferable postmodern view of history as made of nothing but small stories (petits récits).

As a 'historical' participant in the theoretical events in the $1980 \mathrm{~s}$ and onwards at the Academy of Copenhagen and in the artistic circles related to them (such as the gallery and publishing house Basilisk), I would like to add a short final reflection here. ${ }^{1}$ In the light of what happens to international culture in this new century - the wars in the Middle East, the Jewish and the Islamic forms of terrorism, the refugee crisis, the new speculative madness of capitalism, and the global ecological crisis - in this gloomy light, the contradiction and opposition between (modern) philosophical rationalisms and the (postmodern) philosophies of desire that 'the Baroque actualization project' foregrounded, as we have seen, may seem less significant or even vanishing. It is very unlikely that an ecstatic, anti-rational spiritualism based on jouissance and folding - Baroque or not could deliver aesthetic and intellectual guidance and help mankind overcome the overwhelming contemporary problems. I agree that classicistic attitudes claiming formal beauty, order, moderation, and general niceness in design, art, decoration, etc., seem irrelevant as 
responses to our critical aesthetic, intellectual, and possibly political aspirations. They have always been. But it appears to me to be a serious misunderstanding to separate rationalism and the Baroque. Descartes is as much a baroque philosopher as Leibniz and Spinoza; they were the fathers of modern rationalism, building their thinking on mathematics and logic, rather than on dogma and tradition. They were the true rebels, alongside the artists. The great themes of the Baroque - themes that shaped modern enlightened thinking - are indeed the themes of rational philosophy: explorations of the conditions of structural stability and instability, of the dynamics of morphogenesis, in mind and matter; of the symbolic conditions of social theatricality of meaning and the intricate relations of power and truth; of the topologies that allow us to think, model, and imagine the spatio-temporal finitenesses and infinities of the universe. One might add that in this perspective, the 'classical' styles are the irrational ones: Compared to the conventionality of the latter, thinking is excess. Excess is the normal state of rational creativity. It is therefore no wonder it migrates from the historical Baroque to the modern panorama of thinking and art. And, to mention an area that the book does not cover: Where would modern music in all its forms be without the Baroque?

Else Marie Bukdahl offers with this generous rhapsody in B, the achievement of a studious lifetime, a portal for all students of the interrelations of philosophy and art to which the Baroque so irresistibly testifies, and which contemporary culture sometimes forgets. Its rich information and many plateaus of reflection, problematic or not, constitute a challenge for future scholars, who may easily find matter for another lifetime of exploration here.

Per Aage Brandt

NOTE

1 See P. Aa. Brandt, «Morphogenèse et rationalité.

Réflexions sur le baroque», in E. M. Bukdahl \& C. Juhl

(eds.), Puissance du Baroque. Les forces, les formes, les rationalités. Paris: Editions Galilée, 1996. 